\begin{tabular}{c|l|l|l}
$\begin{array}{c}\text { Case Reports in } \\
\text { Demmatology }\end{array}$ & $\begin{array}{l}\text { Case Rep Dermatol 2010;2:195-200 } \\
\text { DOI: } 10.1159 / 000323148\end{array}$ & $\begin{array}{l}\text { Published online: } \\
\text { December 17, 2010 }\end{array}$ & $\begin{array}{l}\text { I 2010 S. Karger AG, Basel } \\
\text { ISSN 1662-6567 } \\
\text { www.karger.com/cde }\end{array}$ \\
\hline
\end{tabular}

\title{
Nodular-Type Lichen Myxedematosus: A Case Report
}

\author{
Azusa Ogita $^{a}$ Naoyuki Higashia ${ }^{a}$ Masaru Hosone ${ }^{b}$ \\ Seiji Kawanac \\ Departments of a Dermatology and ${ }^{b}$ Pathology, Nippon Medical School \\ Tamanagayama Hospital, and 'Department of Dermatology, Nippon Medical \\ School, Tokyo, Japan
}

\section{Key Words}

Alcian blue · Lichen myxedematosus · Mucin · Nodular type

\begin{abstract}
An 18-year-old Japanese woman noticed a progressive appearance of nodules on both forearms and on the left cubital fossa and left thigh one year before her initial consultation at our department. Physical examination showed elastic hard, slightly elevated, shiny and yellowish to skin-colored nodules of 6 to $10 \mathrm{~mm}$ in size on her extremities. From laboratory and histopathological findings, nodular-type lichen myxedematosus was diagnosed and nodules showed complete remission following local injection of triamcinolone acetonide.
\end{abstract}

\section{Introduction}

Lichen myxedematosus (LM) is a primary mucinosis that is not accompanied by thyroid disease. In the updated classification of LM given by Rongioletti et al. [1, 2], the nodular type is one subset of LM that is characterized by multiple nodules on the limbs and trunk with mild or absent papular eruption. The pathogenesis of LM is unknown. Herein, we report a case of nodular-type LM for which local injection of corticosteroids was effective.

\section{Case Report}

An 18-year-old Japanese woman noticed a progressive appearance of nodules on both forearms and on the left cubital fossa and left thigh one year before her initial consultation at our department for further evaluation in 2008. Her past history included absence seizure.

Physical examination revealed elastic hard, slightly elevated, shiny and yellowish to skin-colored nodules of 6 to $10 \mathrm{~mm}$ in size on her extremities without confluence into plaque. She had one nodule on 
the right forearm (fig. 1), three on the left forearm, four on the left cubital fossa, and two on the left thigh. The nodules were not itchy.

Laboratory findings for liver function, free T3, free T4, thyroid-stimulating hormone, fasting blood sugar, and HbA1c were all within normal limits. Hepatitis B and C virus and HIV were negative. Monoclonal gammopathy and M protein were absent. Bence-Jones-protein was not detected in the urine.

Xanthoma and dermatofibroma were suspected based on the clinical appearance, and one nodule on the right forearm was taken for skin biopsy. Histopathologically, collagen fibers were separated in the reticular to deep dermis without epidermal changes (fig. 2a). In a higher magnification view, basophilic mucin deposits between collagen fibers with proliferation of fibroblasts and infiltration of lymphocytes and plasmacytes around vessels were seen in the dermis. Histochemically, the mucin was positive for Alcian blue and negative after hyaluronidase digestion (fig. 2b). From these findings, a diagnosis of nodular LM was made.

Treatment with betamethasone dipropionate ointment was ineffective, but one nodule was completely eliminated by local injection of $0.02 \mathrm{ml}$ triamcinolone acetonide $(8 \mathrm{mg} / \mathrm{ml})$. Since triamcinolone acetonide was subsequently recalled and was unavailable for a period, we tried local injections of $0.1 \mathrm{mg}$ prednisolone sodium succinate three times for each nodule. However, these injections were ineffective. After triamcinolone acetonide reappeared in the Japanese market, local injection of 0.02 to $0.05 \mathrm{ml}$ triamcinolone acetonide was performed and another three injected nodules were completely eliminated.

\section{Discussion}

LM (papular mucinosis) is a disorder characterized by lichenoid papules, nodules and/or plaques due to dermal mucin deposition, and a variable degree of fibrosis without thyroid dysfunction [1]. In an updated classification [1,2], LM is divided into the following clinicopathologic subsets: (1) a generalized papular and sclerodermoid form (scleromyxedema) with monoclonal gammopathy and systemic manifestations that may be lethal. Histologically, the skin shows a microscopic triad of mucin deposition, fibroblast proliferation, and fibrosis; (2) localized LM, which is a papular or nodular/plaque eruption without sclerotic features, monoclonal gammopathy, or systemic involvement; here, the skin shows mucin deposition with variable fibroblast proliferation; and (3) atypical forms, which have atypical features or features intermediate between scleromyxedema and localized LM.

Localized LM is further subdivided into the following four subtypes: (1) discrete LM, which has firm, smooth, waxy or flesh-colored papules of 2 to $5 \mathrm{~mm}$ in size, numbering a few to hundreds on the limbs and trunk in a symmetric pattern. The papules are isolated or form confluent nodules or plaque and rarely resolve spontaneously [1]; (2) acral persistent papular mucinosis, which is characterized by a few to multiple, ivory to fleshcolored papules of 2 to $5 \mathrm{~mm}$ in size on the back of the hands, wrists, and occasionally the distal aspect of the forearms. Papules persist or increase without spontaneous resolution and occur predominantly in females [3]; (3) cutaneous mucinosis of infancy, characterized by firm, opalescent papules located on the upper arms, especially the elbows, and the trunk without spontaneous resolution [1], and (4) nodular-type LM, characterized by multiple nodules on the limbs and trunk, with a mild or absent papular component [2].

Our case was diagnosed as nodular-type LM based on the clinical and histological features. The patient had 8 nodules of 6 to $10 \mathrm{~mm}$ in size on the legs and forearms without a symmetric pattern, whereas papules on the limbs and trunk more commonly occur in a 
symmetric pattern in discrete LM, and occur on the back of the hands and extensor surface of the distal forearms in acral persistent papular mucinosis. Histological findings, such as mucin deposition with variable fibroblast proliferation and the absence of monoclonal gammopathy and M protein, provided further reasons for the diagnosis of nodular-type LM.

Only three previous cases $[4,5]$ characterized by nodular-type LM have been reported, including one from Japan. The mean onset age of the four reported patients with nodulartype LM, including our case, was 30.5 years (range 18-48 years), which suggests that this subtype appears at a younger age compared to discrete LM and acral persistent papular mucinosis. Moreover, three of the four cases were male (table 1). A standard treatment for localized LM is not described in the literature, but in our case nodules showed complete remission following local injection of triamcinolone acetonide, which suggests that this drug may be of some benefit for this condition.

\section{Acknowledgement}

We would like to express our gratitude to Dr. Nobutsugu Zaima for the patient care.

Table 1. Cases of nodular-type lichen myxedematosus

\begin{tabular}{lllllll}
\hline Year & Country & Age/sex & Location & Size, mm & Itch & Treatment \\
\hline $1980[4]$ & Germany & $48 / \mathrm{M}$ & upper legs & $3-15$ & no & $\begin{array}{l}\text { injections of hyaluronidase } \\
\text { (partial regression) }\end{array}$ \\
\hline 1991 & Japan & $24 / \mathrm{M}$ & forearms & about 7-9 & no & steroid ointment (not effective) \\
\hline $1991[5]$ & Switzerland & $32 / \mathrm{M}$ & $\begin{array}{l}\text { right part of the trunk } \\
\text { right-sided proximal extremities }\end{array}$ & $5-20$ & no & no treatment \\
\hline Our case & Japan & 18/F & $\begin{array}{l}\text { forearms, left cubital fossa } \\
\text { left thigh }\end{array}$ & $6-10$ & no & $\begin{array}{l}\text { injections of triamcinolone } \\
\text { acetonide (regression) }\end{array}$ \\
\hline
\end{tabular}




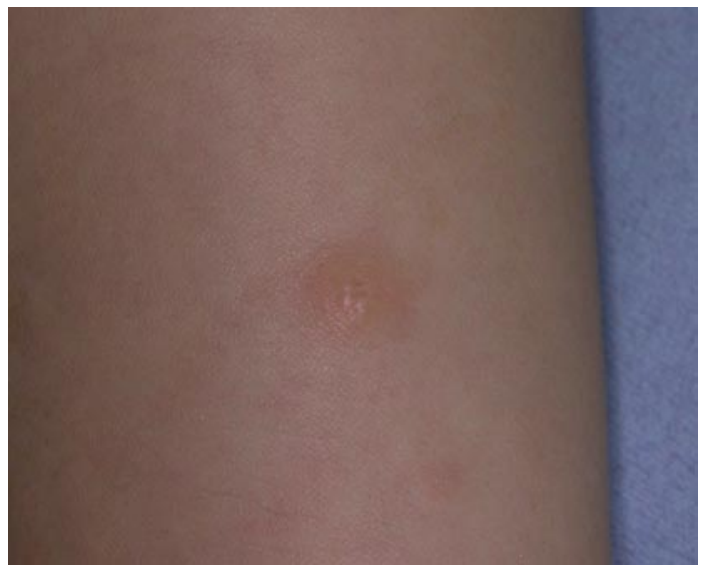

Fig. 1. A shiny and yellowish to skin-colored nodule of about $10 \mathrm{~mm}$ in size on the right forearm was taken for skin biopsy. 


\begin{tabular}{c|l|l|l}
$\begin{array}{c}\text { Case Reports in } \\
\text { Demmatology }\end{array}$ & $\begin{array}{l}\text { Case Rep Dermatol 2010;2:195-200 } \\
\text { DOI: } 10.1159 / 000323148\end{array}$ & $\begin{array}{l}\text { Published online: } \\
\text { December 17, 2010 }\end{array}$ & $\begin{array}{l}\text { O 2010 S. Karger AG, Basel } \\
\text { ISSN 1662-6567 } \\
\text { www.karger.com/cde }\end{array}$ \\
\hline
\end{tabular}
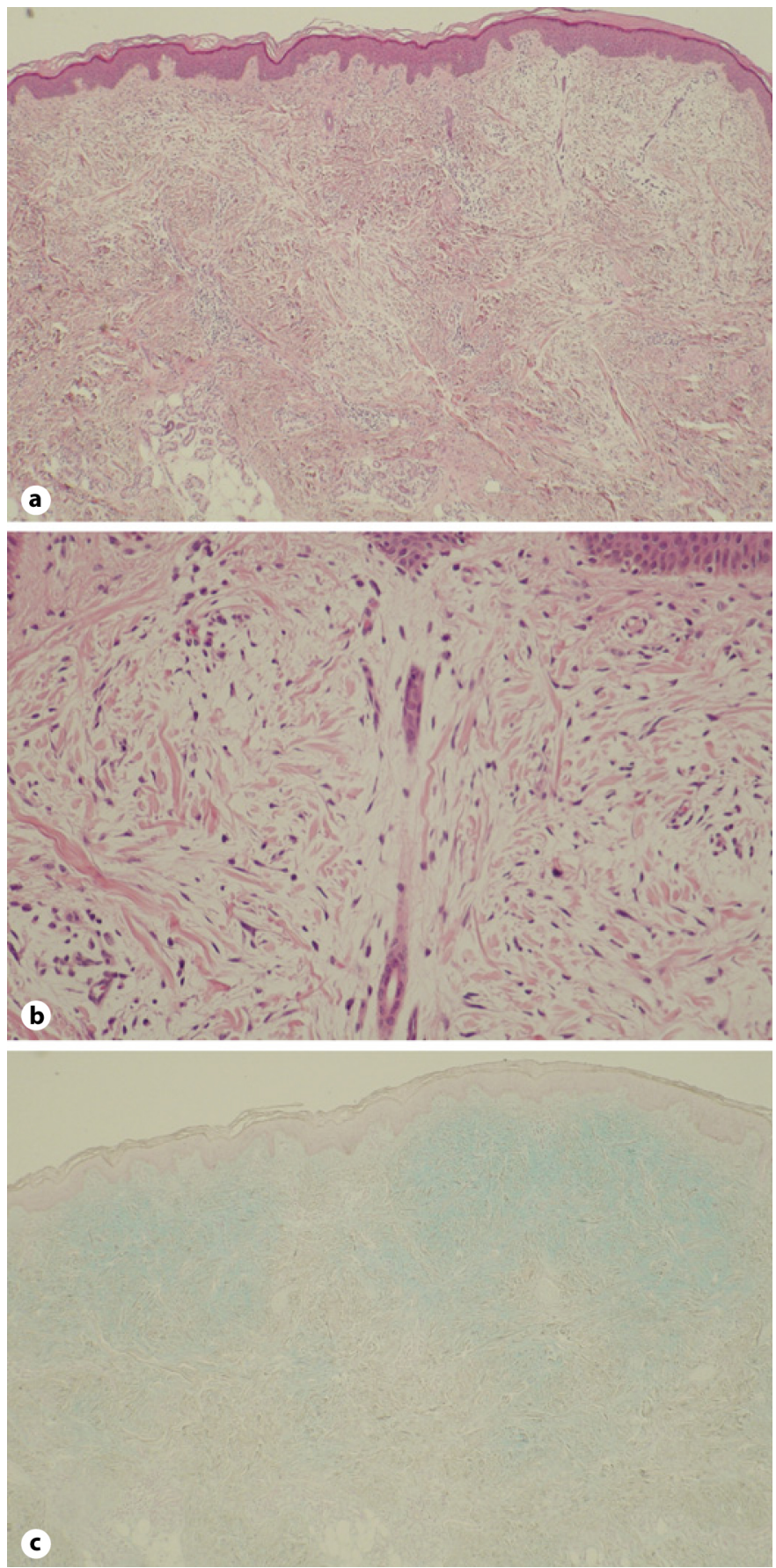

Fig. 2. a Collagen fibers were separated in the reticular layer to deep dermis without epidermal changes. b Mucin deposits between collagen fibers with proliferation of fibroblasts. $\mathbf{c}$ The mucin was positive for Alcian blue staining.

\section{References}

1 Rongioletti F, Rebora A: Updated classification of papular mucinosis, lichen myxedematosus, and scleromyxedema. J Am Acad Dermatol 2001;44:273-281. 
2 Rongioletti F: Lichen myxedematosus (papular mucinosis): New concepts and perspectives for an old disease. Semin Cutan Med Surg 2006;25:100-104.

3 Harris JE, Purcell SM, Griffin TD: Acral persistent papular mucinosis. J Am Acad Dermatol 2004;51:982-988.

4 Suter L, Vakilzadeh F, Macher E: Atypical tuberous myxedema Jadassohn-Dössekker. Report of a case. Dermatologica 1980;161:265-269.

5 Schneider BV, Hohl D, Schnyder UW: Nodular cutaneous mucinosis. An unusual type of euthyreotic focal mucinosis. Dermatologica 1991;183:73-76. 